\title{
Los orígenes de la Unión del Pueblo Navarro (1979-1991)
}

\section{Oscar Barberà}

London School of Economics and Political Science

O.Barbera@lse.ac.uk

\section{Resumen}

El objetivo de este artículo es contribuir a hacer comprender los orígenes y las primeras transformaciones organizativas de la Unión del Pueblo Navarro (UPN). Este trabajo pretende establecer si el modelo de partido que caracteriza a la UPN está más cerca de los partidos profesionales electorales que surgen en Europa con la tercera ola democratizadora o del modelo de partido de masas que históricamente ha caracterizado a los partidos regionalistas en Europa. Las conclusiones señalan como el importante papel del liderazgo, el rápido acceso a las instituciones o la debilidad organizativa inicial sitúan a la UPN mucho más cerca del partido profesional electoral (o catch-all) que de los partidos de masas u otros modelos intermedios.

Palabras clave: UPN, partidos políticos, orígenes, derecha, Navarra.

\section{Abstract. The origins of the Union del Pueblo Navarro (1979-1991)}

The main purpose of this article is to contribute to the understanding of the origins and the first organizational changes made by the Unión del Pueblo Navarro (UPN). In this sense, the article tries to establish whether the UPN is closer to the electoral-professional party model emerged in Europe's third wave of democratization, or to the mass party model that traditionally has characterized most regionalist parties. The conclusions shows how the important role of party leadership, the quick access to the institutions and the fragile party strength during the firsts years set the UPN closer to the electoral-professional party model.

Key words: UPN, political parties, origins, right, Navarre.

\section{Sumario}

Introducción II. La transformación del modelo origina-

I. Formación del partido (1979-1985): UPN y la crisis de UCD rio: de la integración de la UCD al pacto entre UPN y el PP (1985-1991)

Conclusiones

Bibliografía 


\section{Introducción ${ }^{1}$}

La obra seminal de Duverger (1957) fue pionera en señalar la influencia que los orígenes de los partidos tenían en su evolución posterior. El marco analítico propuesto por Duverger sugería que la posición institucional del partido era clave, tanto en la forma organizativa inicial, como en su evolución posterior. Los orígenes de los primeros partidos se fundaban en la afinidad de intereses entre los distintos grupos sociales representados en los parlamentos decimonónicos. La notabilidad social de sus representantes requirió de una débil estructura organizativa hasta la extensión del sufragio universal. Ello favoreció la aparición de los llamados partidos de notables: partidos fuertemente descentralizados, organizados sobre la base de alianzas parlamentarias de los notables locales, muy débilmente articulados y sin muchos más miembros que los mismos representantes. En cambio, los partidos que se crearon fuera del parlamento tuvieron que construir fuertes organizaciones de masas para poder sobrevivir. En muchos casos, estas organizaciones dependieron del apoyo de grupos externos (sindicatos, grupos de intelectuales) para desarrollarse. Ello favoreció la creación de los llamados partidos de masas: partidos fuertemente articulados y centralizados, con estructuras pensadas para articular la participación de grandes cantidades de miembros sin muchos recursos económicos. En estos partidos, la autoridad recaía en los líderes de la organización, no en los parlamentarios.

El esquema de Duverger ha sido refinado por la literatura posterior. Partiendo del marco analítico de Eliassen y Svaasand (1975), Panebianco (1990) estableció distintas circunstancias que pueden darse en el momento de fundar los partidos y que influyen decisivamente en el tipo de partido adoptado: la manera como éste inicia y desarrolla la construcción de la organización (difusión y penetración territorial); la presencia o ausencia de una institución externa que patrocine directamente el origen del partido, y la existencia o no de un líder carismático. Una de las principales aportaciones de Panebianco consistió en subrayar, más allá de la posición institucional (gobierno, oposición, extraparlamentaria) señalada por Duverger, la influencia que estas condiciones iniciales tienen en los orígenes y en la institucionalización de los partidos políticos.

Siguiendo la obra de Kirchheimer (1966), Panebianco sugirió la necesidad de distinguir entre los partidos burocráticos de masas y los partidos electorales profesionales (Panebianco, 1990: cap. 14). Dado que la atención de Panebianco se centró en las democracias europeas avanzadas, el modelo de

1. Una versión previa de este texto fue presentado en el Workshop «La organización de los partidos de ámbito no estatal en España», celebrado en el Institut de Ciències Polítiques i Socials de Barcelona los días 2 y 3 de febrero de 2008. El autor quiere agradecer a Gerard Mestre y Gemma Lechago su colaboración en las tareas de documentación. Este artículo ha sido posible gracias a una beca postdoctoral concedida por el Ministerio de Educación y Ciencia y se enmarca en el Proyecto de Investigación SEJ2006-15076-C0302/CPOL. 
partido electoral profesional fue presentado como una forma de evolución organizativa de los modelos propuestos por Duverger, especialmente del partido de masas (Katz y Mair, 1995; Krowel, 2006). La publicación de la obra de Panebianco coincidió temporalmente con las primeras transiciones políticas de los países de la tercera ola democratizadora. Uno de los rasgos distintivos de muchos de los nuevos partidos nacidos en el sur y en el este de Europa ha consistido, más allá de lo sugerido por Panebianco, en su formación como partidos profesionales electorales (Kopecky, 1995; Lewis, 2000; Diamandouros y Gunther, 2001; Bugajski, 2002; Kostelecky, 2003, Van Biezen, 2003). Conviene señalar, como también lo hacen los especialistas, que éste no es el único modelo organizativo desarrollado por los partidos de las nuevas democracias europeas. Muchos partidos excomunistas todavía conservan importantes vestigios de sus orígenes como formaciones de masas. A ello hay que añadir la aparición de nuevos tipos de partidos, como el cartel (Katz y Mair, 1995), el bussiness firm party (Hopkin y Paolucci, 1999) o el modern cadre party (Koole, 1994).

El propósito de este artículo consiste en mostrar hasta qué punto la formación de la Unión del Pueblo Navarro (UPN), un caso nunca antes abordado académicamente, coincide con la de un partido electoral profesional o, en cambio, sigue pautas más propias de los partidos regionalistas o de ámbito no estatal como la de los partidos de masas (Seiler, 1982; De Winter, 1998). La estructura es como sigue: la primera parte está dedicada a estudiar los factores presentes en la fundación del partido y cómo éstos inciden en su modelo originario (1979-1985). La segunda (1985-1991) analiza los problemas de crecimiento derivados de su rápida subida electoral hasta poco antes de su alianza con el Partido Popular.

\section{Formación del partido (1979-1985): UPN y la crisis de UCD}

La razón fundamental que da origen a la creación de la Unión del Pueblo Navarro (UPN) es, sin duda, el malestar que surge en una parte de la sociedad navarra ante la posibilidad, abierta por la disposición transitoria cuarta de la Constitución española de 1978, de incorporar Navarra al País Vasco ${ }^{2}$. Pese a que la Constitución española reconoce los derechos forales (disposición adicional primera) y ofrece a Navarra diversas vías para decidir su futuro, la existencia de esta cláusula favorecerá que una parte de la derecha se movilice en defensa de su existencia diferenciada dentro del Estado español ${ }^{3}$.

2. Sobre la disposición transitoria cuarta, véanse las obras de Pérez Calvo (1999), Razquin (1989) y Santamaría Pastor (1992).

3. «UPN se define como partido foralista, de centro reformista y social. Objetivo esencial de su acción política es la defensa y desarrollo de la identidad de Navarra, de sus derechos originarios e históricos, y de su permanencia como Comunidad Foral propia, diferenciada e integrada en la nación española y por ende formando parte de la Unión Europea», artículo 2 de los Estatutos de la UPN (2005). 
La creación de la UPN está liderada por Jesús Aizpún ${ }^{4}$, el cabeza de lista de Unión del Centro Democrático (UCD) por Navarra en las elecciones generales de 1977. Durante la última etapa del proceso constituyente, Aizpún empieza a mostrar públicamente sus diferencias por la inclusión de la disposición transitoria cuarta en la Constitución, y acusa a Suárez de querer encuadrar Navarra en el País Vasco ${ }^{5}$. Como muestra de rechazo, Aizpún decide abstenerse en la votación final del proyecto constitucional ${ }^{6} \mathrm{y}$, poco después, abandonar tanto el grupo parlamentario como el partido ${ }^{7}$.

La aprobación de la Constitución, la convocatoria de elecciones generales y, sobre todo, municipales, acelera el proceso de creación del nuevo partido ${ }^{8}$ : Unión del Pueblo Navarro se constituye el 3 de enero de $1979^{9}$. El núcleo inicial de dirigentes que firma el acta de constitución está integrado por (tabla 1): Jesús Aizpún, José Angel Zubiaur, María Isabel Beriáin, Javier Gómara, Ramón Echevarría, Feliciano Aramendía y Jose Javier Chourraut ${ }^{10}$.

Buena parte de estos dirigentes son los que ocupan los principales lugares de dirección en el congreso fundacional del partido, que se celebra los días 7 y 8 de enero de 1979. En este congreso, la presidencia del partido es asignada a Javier Gómara, la vicepresidencia recae en José Antonio Andía, mientras que Miguel Iraburu es nombrado secretario y Feliciano Aramendía, tesorero ${ }^{11}$. Pese

4. La trayectoria política de Aizpún antes de su integración en la UCD empieza en 1964, cuando fundó la «Unión Navarra, perteneció al Consejo Foral de Navarra y creó el Partido Demócrata Liberal hasta que se integró en UCD, formación con la que concurrió en 1977 a los primeros comicios legislativos» (El Mundo, 30 de diciembre de 1999). A parte de esta actividad política, Aizpún tiene numerosas conexiones empresariales. Según se informa, a finales de los años ochenta éste tiene relación con diversas empresas, como Industrias Metálicas de Navarra, Girling España SA y Material Auxiliar de Petróleos (El País, 25 de abril de 1988).

5. «[...] la tendencia del entonces presidente, Adolfo Suárez, a encuadrarnos en la Comunidad Autónoma Vasca [...] Querían dejar una puerta abierta y me pareció que la personalidad de Navarra no estaba suficientemente defendida desde UCD y que hacía falta un partido netamente navarro que defendiera la identidad de Navarra y respetara su foralidad» (El Mundo, 30 de diciembre de 1999). Aizpún funda esta visión de la UCD no sólo en la Constitución, sino también en los reales decretos 1/1978 y 2/1978 que la preceden.

6 «Como navarro que deseo continuar incorporado a España sin entes políticos intermedios, y como español que se preocupa gravemente de las posibilidades de una actuación separatista patrocinada por muchos partidos vascos, no puedo dar mi voto a este texto de la Constitución» (El País, 2 de noviembre de 1978).

7. El Pais, 16 de noviembre de 1978.

8. Aizpún anuncia la creación de un partido regionalista navarro a finales de noviembre de 1978 del que fija, a su vez, buena parte de su programa político «se inspirará en el humanismo cristiano, defenderá la iniciativa privada y adoptará una postura clara contra el marxismo y el separatismo" (El País, 23 de noviembre de 1978).

9. El proceso de legalización del partido es cumplido sin problemas pocos días después, el 5 de enero de 1979 (El País, 6 de enero de 1979).

10. También vinculados al proceso de fundación, aparecen José Antonio Andía, Ángel y Jesús Marrodán, Antonio Maeztu y Miguel Iraburu. Al parecer, éste último fue el que propuso el nombre del partido (Por Navarra, febrero de 2004).

11. El resto del Comité Ejecutivo lo integran, como vocales, José Luis Garicano, José Ángel Zubiaur, Jesús Aizpún, Antonio Lavín, Jesús Andía Ustárroz, Jesús Marrodán, Javier Chorraut y Javier del Castillo (Diario de Navarra, 8 de noviembre de 1981: 10). 
a que Aizpún rechaza tener un papel destacado dentro de la organización, su ascendente político sobre este grupo es claro ${ }^{12}$.

El liderazgo de Aizpún, el reducido número inicial de miembros y la necesidad de preparar las inminentes elecciones generales y autonómicas de 1979 favorece la adopción de un modelo organizativo extremadamente centralizado y con el poder concentrado casi exclusivamente en el Comité Ejecutivo ${ }^{13}$. Pese a su estado todavía embrionario, el modelo organizativo que pretende desarrollarse presenta diversas características que lo alejan de los partidos de masas para acercarlo a modelos como el partido electoral profesional (Panebianco, 1990: 487 y s.), el modern cadre party (Koole, 1994: 297 y s.) o el catch-all (Kirchheimer, 1966). Ello es visible en diversos elementos:

a) En primer lugar, no existe ninguna organización externa que lo patrocine, de ahí que su organización sea inicialmente muy débil. De hecho, en 1979, el partido sólo cuenta con un comité local (en Pamplona) y ni siquiera es capaz de tener estructurada su base territorial por toda la provincia ${ }^{14}$.

b) Es más, la existencia de la UCD dificulta hasta 1982-1983 la captación de nuevos cuadros y adherentes, por lo que su crecimiento será, hasta entonces, muy lento y por penetración ${ }^{15}$. Entre 1979 y 1981, el partido dobla su número de afiliados, que pasa de 200 a 400 (muy mayoritariamente, hombres y residentes en Pamplona ${ }^{16}$.

c) Este lento crecimiento en término de miembros contrasta con su rápido crecimiento electoral: sólo en 1979 ya consigue pasar de 28.248 votos en las elecciones generales a los 40.764 votos de las elecciones al Parlamento Foral.

d) El rápido crecimiento electoral del partido se debe, en parte, al liderazgo y a la habilidad de su principal promotor, Jesús Aizpún, para explotar el

12. Años más tarde, Aizpún dirá "Cuando creamos el partido nadie me hubiera discutido la presidencia si ésa hubiera sido mi aspiración. Y por el contrario yo me preocupé de no figurar en ningún cargo directivo, sinó de mero vocal del comité, precisamente para que el partido no se identificara con mi persona. Lo que yo quería hacer es partido y eso es lo que he hecho en estos seis años" (Diario de Navarra, 2 de febrero de 1985: 29).

13. Aizpún dice, en 1981, «UPN nació en condiciones muy especiales, porque, estando ya convocadas las elecciones, inicialmente tuvo que ser necesariamente una máquina electoral antes que un partido organizado. Después ha tenido que afrontar unas responsabilidades a nivel parlamentario tanto en Madrid como en Navarra que lógicamente han absorbido la actividad de sus miembros" (Diario de Navarra, 7 de noviembre de 1981: 30).

14. «Cuando se fundó, el partido sólo contaba con una sede, prestada por la Sociedad Cultural Leyre, de 30 metros cuadrados, situada en el centro de Pamplona [y] con un [solo comité local] en Pamplona y 5 comités de merindad» (Por Navarra, febrero de 2004: 4).

15. «Los primeros pasos de la implantación de la UPN en las diversas localidades han quedado registrados en unos cuadernos, donde los responsables del partido anotaban las visitas que realizaban a pueblos y los encuentros que mantenían [...] que reflejan las dificultades con las que se encontraron y el panorama político local» (Por Navarra, febrero de 2004: 10).

16. «Al finalizar 1979, UPN contaba con menos de 200 afiliados, de los cuales casi un $80 \%$ eran hombres y el 20\% restante eran mujeres. Estos primeros socios se localizaban principalmente en Pamplona y en la Ribera» (Por Navarra, febrero de 2004: 4). 
descontento de una parte de los votantes con la posible incorporación de Navarra al País Vasco.

e) El rápido crecimiento electoral, junto a la ausencia patrocinadores externos y de una masa crítica de afiliados, hace muy difícil que la financiación del partido no provenga de otra fuente que no sean fondos públicos.

f) Pese a que se organiza formalmente como un típico partido de masas con afiliación directa, estructura local y territorial (merindades), y la elección de la dirección a través de un congreso, esta estructura servirá inicialmente de poco. El protagonismo residirá, en cambio, en el grupo de parlamentarios profesionales estrechamente vinculados a Aizpún.

g) La aparente bicefalia que Aizpún propicia al renunciar inicialmente a su cargo de presidente del partido, no se corresponderá con la bicefalia típica de los partidos de masas entre la dirección orgánica y el grupo parlamentario. Ésta parece obedecer, por el contrario, a razones de distribución funcional de los cargos entre los principales miembros de la dirección: Aizpún es designado como cabeza de lista del partido para las elecciones generales; Javier Gómara lo es para el Parlamento Foral.

De cara a las elecciones generales de 1979, Aizpún parece llegar a algún tipo de acuerdo para que la Coalición Democrática (CD) de Manuel Fraga no se presente por Navarra ${ }^{17}$. A cambio, Fraga parece contar con la integración de la UPN dentro de CD. Con todo, estas elecciones marcan ya el primer desencuentro entre Aizpún y Fraga. Una vez pasados los comicios, la UPN rechaza toda vinculación con CD y decide que su único diputado (Azipún) se integre en el grupo mixto ${ }^{18}$. El resultado de estos comicios muestra la fuerza del nuevo partido, pues éste se sitúa de inmediato como tercera fuerza política, aunque todavía a mucha distancia de la UCD y el PSOE.

El problema de la integración al País Vasco es uno de los puntos centrales de la campaña para las elecciones generales de 1979 en Navarra. Con todo, es con la convocatoria de las elecciones al Parlamento Foral de Navarra que esta cuestión se plantea abiertamente. Ésta es, de hecho, una de las principales razones por la que se constituye el Parlamento Foral ${ }^{19}$. En esta campaña, todos los partidos toman ya una posición inicial respecto a esta cuestión. La UPN rechaza de plano no sólo la incorporación, sino que ésta deba plantearse en el

17. Alianza Popular tuvo serios problemas para implantarse en Navarra durante las elecciones de 1977.

18. El 7 de marzo de 1979, UPN hace público un comunicado donde asegura que la UPN «no está integrado ni tiene vinculación con CD» (El País, 8 de marzo de 1979), al que los dirigentes de CD replican que «evidentemente, no había un acuerdo electoral expreso con el señor Aizpún, pero sí un compromiso moral claro» (El Pais, 9 de marzo de 1979).

19. Artículo 3.1 del Real Decreto Paccionado, 121/1979 de 26 de enero. Este Parlamento es una institución a medio camino entre asamblea legislativa y pleno de Diputación Provincial. Éste posee capacidad legislativa, pero no la iniciativa, que depende de la Diputación Foral (Ramos e Innerarity, 1998: 404). 
Tabla 1. Miembros del Comité Ejecutivo del partido y cargo en cada congreso (1979-1989)

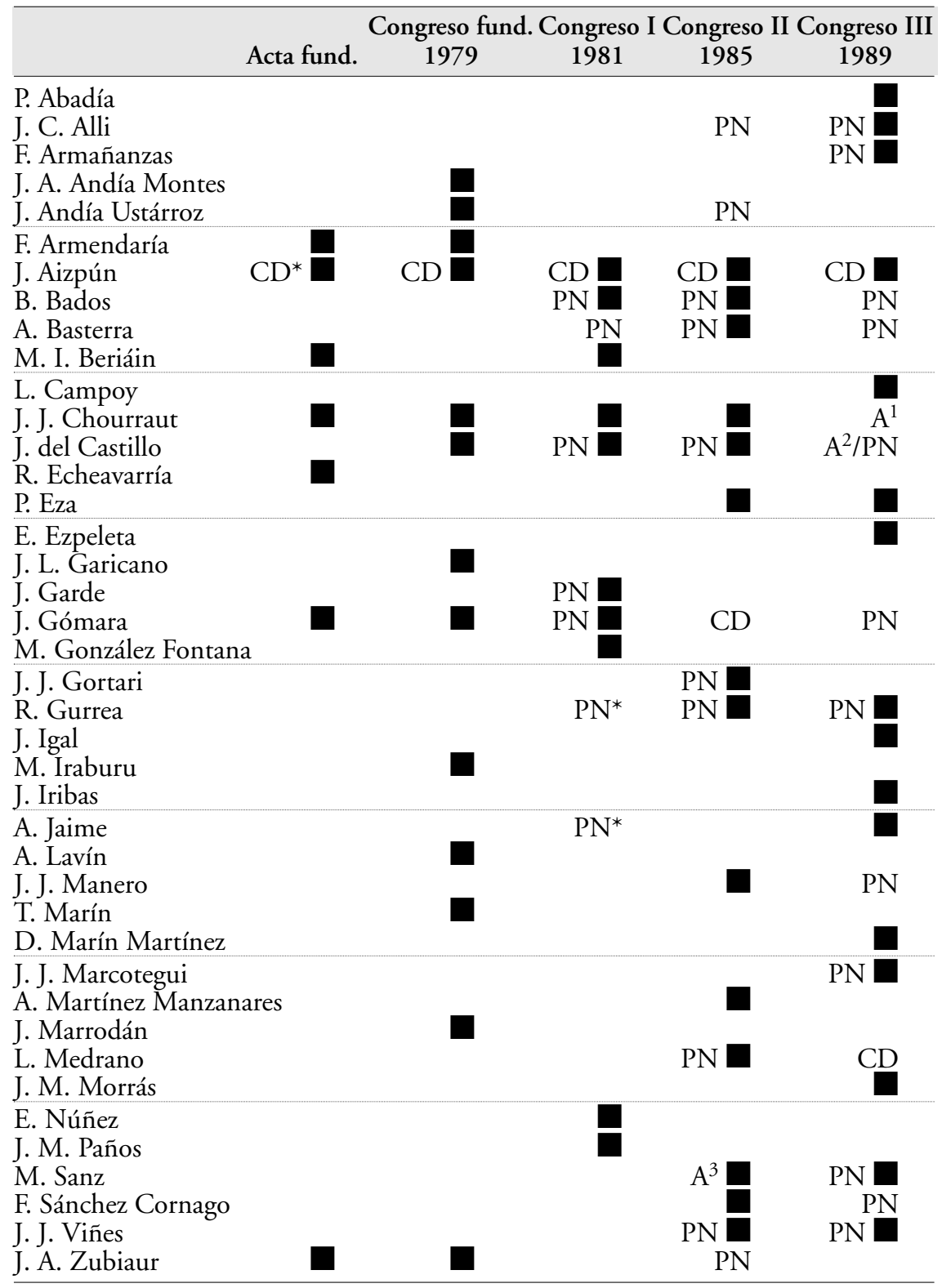

Fuente: elaboración propia.

Las letras expresan el cargo público en el momento de realizar el congreso.

El asterisco significa que se trataba de un diputado por UCD.

Recuadro negro, los miembros del Comité Ejecutivo.

Siglas: PN: Parlamento Foral; CD: Congreso de los Diputados; S: Senador; J: Presidente Juventudes (Nato).

1. Alcalde de Pamplona; 2. Alcalde de Sangüesa; 3. Alcalde de Corella. 
Parlamento. Y, a su vez, no deja de insistir tanto en la voluntad anexionista vasca, como en el entreguismo de Suárez ${ }^{20}$. Sin embargo, la UCD Navarra (presidida por J. I. del Burgo) tampoco se muestra partidaria ni de la integración ni de plantearla en el parlamento ${ }^{21}$. El PSOE, que históricamente había defendido la incorporación, opta en estos momentos para posponer el referéndum durante cuatro años 22 . $\mathrm{HB}$, por su parte, se niega a convocar ningún referéndum porque "Euskadi no puede existir sin Navarra» ${ }^{23}$. El PNV, por su parte, se muestra partidario tanto de plantear la cuestión en el Parlamento como de la integración.

El resultado de las elecciones al Parlamento Foral ratifica, como ya lo hicieron las generales, que la UPN es la tercera fuerza política Navarra sólo detrás de la UCD y del PSOE (tabla 2). Los comicios son electoralmente muy favorables a la UPN, pues obtiene 13 parlamentarios forales, gana 12.000 votos respecto a las elecciones generales de 1979 y consigue reducir substancialmente su distancia con los dos primeros partidos. Pese a la relativa homogeneidad de su asentamiento electoral en toda Navarra, lo cierto es que la principal zona de implantación del partido es en Pamplona y la zona de la Ribera (Valentín, 1991). Pese al aumento electoral de la UPN, las singulares características de estas elecciones ${ }^{24}$, junto a los criterios establecidos para formar el primer gobierno ${ }^{25}$, dejan a la UPN fuera de la Diputación Foral, presidida por Jaime Ignacio del Burgo (UCD). Las elecciones al Parlamento Foral muestran un notable grado de fragmentación y polarización del espectro político articulado entorno a cuatro principales fuerzas políticas UCD, PSOE, UPN y HB (Llera, 1989: 511). Ello dificultará substancialmente la gobernabilidad durante esta legislatura.

En las elecciones municipales de 1979, la UPN obtiene cuarenta y seis concejales, tres alcaldes y cinco concejales en el Parlamento de Pamplona ${ }^{26}$. Pese a quedar fuera de la Diputación Foral y del Gobierno del Ayuntamiento de Pamplona, los resultados de las elecciones al Parlamento Foral y de las elec-

20. A título de ejemplo, el 24 de mayo de 1979, Aizpún publica una carta en El País, donde sostiene que la UCD y el PNV han pactado ya los términos de la independencia de Euskadi.

21. «Para UCD lo vasco es consubstancial a Navarra, y en esta línea potenciará la cultura euskérica, pero sin llegar a ningún tipo de unión con Álava, Gipúzcoa y Vizcaya» (El País, 31 de marzo de 1979).

22. El Pais, 31 de marzo de 1979. Conviene recordar que no es hasta 1982 que se crea el Partido Socialista Navarro. Hasta entonces, los dirigentes del PSOE navarro se encuadran dentro del Partido Socialista Vasco.

23. El País, 31 de marzo de 1979.

24. Se eligieron a 70 parlamentarios. Cada merindad histórica se constituyó en distrito electoral (salvo Pamplona, que se dividió en dos distritos) y eligió a un número de parlamentarios proporcional a los electores que reunía. Ello tendió a generar un subsistema de partidos pluralista polarizado y fuertemente centrífugo (Llera, 1997: 506).

25. El Gobierno de Navarra que se constituyó tras estas elecciones fue una corporación de siete miembros compuesta por los candidatos del partido más votado en cada distrito electoral (de los dos partidos más votados en el caso de la merindad de Tudela).

26. Por Navarra, febrero de 2004: 04. 
Tabla 2. Resultados para el Congreso de los Diputados y el Parlamento Navarro (1977-1979)

\begin{tabular}{|c|c|c|c|c|c|c|c|c|c|}
\hline \multirow[b]{2}{*}{ Partido } & \multicolumn{3}{|c|}{1977 G } & \multicolumn{3}{|c|}{1979 G } & \multicolumn{3}{|c|}{1979 PFN } \\
\hline & Votos & $\%$ & E & Votos & $\%$ & $\mathrm{E}$ & Votos & $\%$ & E \\
\hline UCD & 75.036 & 29,0 & 3 & 83.302 & 21,9 & 1 & 68.040 & 26,8 & 20 \\
\hline PSOE & 54.720 & 21,2 & 2 & 55.399 & 21,9 & 1 & 48.289 & 19,0 & 15 \\
\hline UPN & - & - & - & 28.248 & 11,2 & 1 & 40.764 & 16,1 & 13 \\
\hline $\mathrm{HB}$ & - & - & - & 22.425 & 8,9 & 0 & 28.244 & 11,1 & 9 \\
\hline UNAI & 24.489 & 9,5 & 0 & 10.970 & 4,3 & 0 & 7.419 & 2,9 & 1 \\
\hline PNV & 10.4501 & - & - & 21.305 & 8,42 & 0 & 12.8452 & 5,1 & 3 \\
\hline PC & - & - & - & 19.522 & 7,7 & 0 & 12.165 & 4,8 & 1 \\
\hline AEM & - & - & - & - & - & - & 17.282 & 6,8 & 7 \\
\hline IFN & - & - & - & - & - & - & 3.729 & 1,5 & 1 \\
\hline
\end{tabular}

Fuente: Ministerio del Interior y Parlamento de Navarra.

En negrita, el partido más votado en cada elección.

1. Equipo DC (PNV).

2. Nacionalistas Vascos (PNV + EE).

Siglas: UCD: Unión de Centro Democrático; PSOE: Partido Socialista Obrero Español; UPN: Unión del Pueblo Navarro; HB: Herri Batasuna; UNAI: Unión Navarra de Izquierda; PNV: Partido Nacionalista Vasco; PC: Partido Carlista; AEM: Agrupaciones Electorales de Merindad; EE: Euskadiko Ezkerra; IFN: Agrupación Electoral Independientes Forales Navarros; CDS: Centro Democrático y Social.

ciones municipales otrogan a la UPN un papel fundamental en esta legislatura. Ello se debe a diversos factores: a la voluntad de consenso entre los grandes partidos (UCD, PSOE y UPN) sobre el futuro institucional de la provincia y a las precarias mayorías de la UCD (en el Parlamento Foral) y el PSOE (en Pamplona).

La primera cuestión que afronta el Parlamento Foral es la de la integración en Euskadi. La propuesta es presentada por el Grupo Mixto en la Comisión de Régimen Foral el día 17 de diciembre de 1979 y rechazada con los votos de la UCD y de la UPN ${ }^{27}$. Cerrada esta vía, el camino que impulsa la Diputación Foral es la del amejoramiento del Fuero de Navarra ${ }^{28}$. El texto de reintegración es aprobado por el Parlamento Foral el 1 de julio de 1980 gracias al acuerdo entre UCD, PSOE y UPN. Los principales elementos del texto son: el reconocimiento preconstitucional del régimen foral (al amparo de la Disposición Adicional Primera de la Constitución 1978); el pleno reconocimiento de la capacidad tributaria de Navarra, y el procedimiento llevado a cabo para su aprobación (negociación entre Gobierno y Diputación Foral). Finalmente, el proceso culmina el 10 de agosto de 1982 con la aprobación de

27. Votaron a favor HB, el PNV y AMAIUR, lo hicieron en contra la UCD y la UPN y se abstuvieron el PSOE y el Partido Carlista (El País, 18 de diciembre de 1979; La Vanguardia, 19 de diciembre de 1979: 13).

28. El País, 28 de diciembre de 1979. 
la Ley Orgánica de Reintegración y Amejoramiento del Régimen Foral de Navarra (LORAFNA) (Razquín, 1989; Loperena, 2002) ${ }^{29}$.

El proceso de desarrollo de las instituciones forales lleva también a otras importantes polémicas: la cooficialidad de la lengua vasca, la bandera, la necesidad de convocar un referéndum sobre el amejoramiento, el reglamento provisional de la cámara y la ley de gobierno. El descontento de la izquierda abertzale ( $\mathrm{HB}$ y Amaiur) respecto a la solución dada a estos temas (junto al caso Del Burgo) motiva su ausencia del Parlamento Foral desde $1981^{30}$.

Además de la construcción de las instituciones forales, la legislatura está marcada, sin duda, por la crisis de la UCD navarra ${ }^{31}$. Este partido sufre, a finales de 1979, una primera escisión (liderada por Pegenaute y Monge) debido a la interpretación que debe hacerse del Estatuto Vasco ante una eventual integración de Navarra. Con todo, el principal problema llega con la publicación de unas presuntas irregularidades cometidas por el presidente de la Diputación Foral, J. I. del Burgo. Esta cuestión abre una nueva crisis dentro de la UCD navarra: mientras la mayoría de la UCD apoya a Del Burgo ${ }^{32}$, una parte del grupo parlamentario foral y los tres miembros elegidos por la UCD en la Diputación Foral facilitan su destitución ${ }^{33}$. Uno de ellos, Juan Manuel Arza es designado presidente, cargo que mantendrá hasta enero de $1984^{34}$. Hasta las elecciones de 1982, ambos sectores viven abiertamente enfrentados.

La UPN también garantiza la estabilidad en Pamplona gracias a su apoyo al PSOE. Ello es particularmente visible desde finales de 1981, cuando HB y PNV impulsan una moción de censura contra el alcalde Julián Balduz por retirar la ikurriña como bandera oficial ${ }^{35}$. Meses más tarde, es UCD quien, por

29. La visión de los protagonistas de las negociaciones puede encontrarse en diversas publicaciones del Parlamento de Navarra (AAVV, 1994; Parlamento de Navarra, 1994). Visiones contrapuestas, en Bermejo y Díez (1990) y Chueca (2002).

30. En contra del texto, votaron el PNV, HB y Amaiur.

31. Ugalde y Arana (1989) y Ramos e Innerarity (1998) defienden la idea que la crisis de la UCD condujo a una parálisis sustancial de las instituciones durante este período.

32. Del Burgo organiza una asamblea que ratifica todas sus decisiones (El País, 27 de abril de 1980 ) y consigue imponerse a los «progresistas» (o sector crítico) en la asamblea provincial de agosto de 1981 (El País, 7 de agosto de 1981).

33. El día 14 de abril de 1980, Arza (independiente), Sánchez de Muniaín (independiente) y Lasunción (UCD) votan en el Parlamento Foral a favor de la propuesta de destitución de Del Burgo como por presidente de la Diputación Foral y como diputado del mismo Parlamento (La Vanguardia, 15 de abril de 1980: 14). Días más tarde, el 28 de abril de 1980, favorecen su destitución efectiva en una votación en la Diputación Foral ( $\mathrm{La}$ Vanguardia, 29 de abril de 1980: 15).

34. Arza es nombrado presidente en funciones desde el 28 de abril hasta el 29 de septiembre de 1980 (El País, 1 de octubre de 1980). Desde entonces y hasta enero de 1984, ejercerá como presidente.

35. La censura no prospera gracias a los votos de la UPN junto al PSOE y a la abstención de los concejales de la UCD (El País, 24 de diciembre de 1981). 
otras razones, también impulsa otra moción de censura que es igualmente derrotada, aunque, esta vez, con la abstención de la UPN ${ }^{36}$.

La crisis de la UCD navarra parece abrir magníficas perspectivas electorales para UPN, que decide organizar su primer congreso para los días 7 y 8 de noviembre de 1981. Frente a la división de UCD, el mensaje central (y casi exclusivo) del congreso es, precisamente, la unidad del partido ${ }^{37}$. Esta unidad no excluye una importante renovación en la composición de sus órganos directivos. De todos modos, los lugares clave continúan ocupados por los fundadores o gente próxima a Aizpún (tabla 1). Así, Javier Gómara es reelegido presidente; Balbino Bados es nombrado vicepresidente; José María Paños, secretario, y Javier Chourraut, tesorero ${ }^{38}$.

Pese a continuar sin responsabilidades destacadas dentro de la dirección (sigue de vocal en el Comité Ejecutivo) ${ }^{39}$, Aizpún centra toda la atención informativa del congreso. No en vano, él es el encargado de dirigir los debates entorno a la ponencia ideológica y quien comparece en todas las ruedas de prensa. Su mensaje, de marcada orientación demócrata-cristiana, va claramente dirigido a captar a los antiguos votantes ucedistas ${ }^{40}$. Aizpún también modera su mensaje alarmista sobre las pretensiones expansionistas vascas que caracterizaron a las campañas electorales de $1979^{41}$.

Con lo que no cuenta la UPN es que el adelanto de las elecciones generales para octubre de 1982 vaya acompañado de la voladura de UCD y, por extensión, de un importante realineamiento en el sistema de partidos español. Navarra no es una excepción a esta tendencia, aunque la dirección del partido (Del Burgo, Gurrea) opta por la continuidad, una parte apuesta por unirse a las filas socialistas (Morodo), otra es la que constituye el principal núcleo de AP (Pegenaute y Monge) y otra decide seguir a Adolfo Suárez en la crea-

36. En este pleno se votan, de hecho, dos mociones de censura. Una de HB y el PNV, que es derrotada de nuevo con los votos de la UPN y el PSOE y la abstención de la UCD, y otra de la UCD, que es derrotada con los votos de HB y el PSOE (El País, 27 de marzo de 1982).

37. No en vano, el lema es "Navarra Unida» (Diario de Navarra, 6 de noviembre de 1981: 9). El único desacuerdo importante del congreso es si la lista del Comité Ejecutivo debe ser abierta o cerrada (Diario de Navarra, 8 de noviembre de 1981: 8).

38. Los vocales son: Jesús Aizpún, Tomás Marín, Maribel Beriain, Miguel González Fontana, Javier del Castillo, Eduardo Núñez y Javier Garde (Diario de Navarra, 8 de noviembre de 1981: 10).

39. En una entrevista en el Diario de Navarra, se pregunta a Aizpún si la UPN es un partido personalista. Su respuesta es clara «Yo creo que si algún partido no es personalista es precisamente UPN, porque, si de alguna forma UPN se identifica con Jesús Aizpún, hay que dejar bien claro que Jesús Aizpún, dentro del partido, es el presidente, ni el vicepresidente ni el secretario general. Es pura y simplemente un vocal más del Comité Ejecutivo».

40. En la ponencia ideológica, se afirma que UPN mantiene «los valores del humanismo cristiano, de la libertad individual, la estabilidad familiar, libertad de enseñanza, propiedad e iniciativas privadas, igualdad personal y de oportunidades y radical solidaridad social» (Diario de Navara, 10 de noviembre de 1981: 30).

41. «UPN representa una opción de foralidad que no tiene nada de antivasquismo» (Diaro de Navarra, 7 de noviembre de 1981: 30). 
ción del Centro Democrático y Social (CDS) (Lasunción y Sánchez de Muniaín).

La división de la derecha navarra abre un incierto panorama electoral para la UPN. Pese a que la opción inicial de Aizpún parece ser el pacto con Fraga ${ }^{42}$, también se sondea la posibilidad de crear una coalición entre UPN, UCD y AP. La negativa de Del Burgo (UCD) a todo acuerdo con los (escindidos) dirigentes de AP, parece decantar finalmente la negociación de una coalición electoral entre UPN y AP. Gracias a este pacto, los diputados de la UPN pasan del grupo mixto al grupo parlamentario de Coalición Popular.

Los resultados de las elecciones generales de 1982 en Navarra (tabla 3), muestran la fuerza ascendente del PSOE, que se convierte en el primer partido de la provincia. Pero, también, el acierto de la política de alianzas de la UPN, que, en esta ocasión, casi dobla su número de votos y pasa a convertirse en la segunda fuerza política de la provincia. Fruto de estos resultados y de los efectos mayoritarios de la ley electoral, la UPN pasa de uno a dos diputados (Aizpún y Gómara) y la coalición consigue un senador (Pegenaute, de AP). Más allá de estas circunstancias, las elecciones muestran la debacle electoral de la UCD y el poco arraigo del $\mathrm{CDS}^{43}$.

La desaparición de la UCD, poco antes de las elecciones municipales y autonómicas de 1983, favorece un nuevo realineamiento en el sistema de partidos navarro (Llera, 1997: 512 y s.). Mientras el presidente de la UCD, Jaime Ignacio del Burgo, se integra en el Partido Demócrata Popular (PDP), otra parte del partido, integrada por Ramón Gurrea ${ }^{44}$, Alfredo Jaime, o José J. Viñes, lo hacen en la UPN. La división de la derecha se mantiene de cara a las elecciones autonómicas de 1983, tanto por las exigencias de la UPN ${ }^{45}$, como por las características del nuevo sistema electoral ${ }^{46}$. Sin la UCD, y con el CDS todavía poco organizado, la competición se centra ahora entre la UPN y la recién formada alianzaAP-PDP. En el caso de la UPN, la elección de Gómara como diputado al Congreso, en 1982, favorece que sea Baibino Bados (vicepresidente de la UPN) quien figure como cabeza de lista $^{47}$.

42. «Aizpún negocia la federación de su grupo con Alianza Popular» (El País, 28 de mayo de 1982).

43. El hecho más relevante es, sin duda, que Del Burgo no consigue obtener el acta de diputado por UCD.

44. Gurrea ha sido secretario general de la UCD navarra y estrecho colaborador de Del Burgo.

45. «En esta ocasión, las condiciones impuestas por la UPN (algunos de cuyos dirigentes consideraron que la coalición con AP-PDP les restó 35.000 votos) fueron estimadas excesivas por los hombres de Manuel Fraga y Óscar Alzaga en Navarra» (El País, 16 de abril de 1983).

46. Pese a que el nuevo parlamento cuenta con 50 diputados en vez de los 70 del Parlamento Foral, los efectos proporcionales derivados de ser provincia única parece favorecer que los distintos partidos intenten presentarse en solitario.

47. Con todo, el país parece apostar porque no será Bados sino Albito Viguria (portavoz en el Parlamento Foral) quien sea propuesto como aspirante a la presidencia del Gobierno ( $E l$ Pais, 16 de abril de 1983). 
Tabla 3. Resultados en las elecciones generales, autonómicas y municipales (1982-1983)

\begin{tabular}{|c|c|c|c|c|c|c|c|c|c|}
\hline \multirow[b]{2}{*}{ Partido } & \multicolumn{3}{|c|}{$1982 \mathrm{G}$} & \multicolumn{3}{|c|}{$1983 \mathrm{G}$} & \multicolumn{3}{|c|}{1983 PFN } \\
\hline & Votos & $\%$ & $\mathrm{E}$ & Votos & $\%$ & $\mathrm{E}$ & Votos & $\%$ & $\mathrm{E}$ \\
\hline UCD & 31.245 & 10,5 & 0 & - & - & - & - & - & - \\
\hline PSN-PSOE & 112.186 & 37,6 & 3 & 94.737 & 35,9 & 20 & 76.431 & 28,9 & 259 \\
\hline UPN & 76.2551 & 25,6 & 2 & 62.072 & 23,5 & 13 & 33.111 & 12,26 & 79 \\
\hline $\mathrm{HB}$ & 34.744 & 11,7 & 0 & 28.055 & 10,6 & 6 & 21.574 & 8,0 & 62 \\
\hline PNV & 16.363 & 5,5 & 0 & 18.161 & 6,9 & 3 & 13.499 & 5,0 & 62 \\
\hline AP-PDP & - & - & - & 37.554 & 14,2 & 8 & 21.134 & 7,8 & 80 \\
\hline
\end{tabular}

Fuente: Ministerio del Interior, Parlamento de Navarra y Heras (1997: 688) para las municipales de 1983 .

En negrita, el partido más votado en cada elección.

1. Coalición UPN-AP-PDP-UPL.

Siglas: UCD: Unión de Centro Democrático; PSOE: Partido Socialista Obrero Español; UPN: Unión del Pueblo Navarro; HB: Herri Batasuna; PNV: Partido Nacionalista Vasco; AP-PDP: Alianza Popular-Partido Demócrata Popular.

Las elecciones municipales muestran el dominio socialista, que consigue obtener la mayoría absoluta en ciudades como Tudela. La incorporación en las listas de la UPN de buena parte de los dirigentes locales de la UCD permite al partido ampliar substancialmente su base de poder territorial ${ }^{48}$. En Pamplona, la candidatura de Juan Cruz Alli ${ }^{49}$ (UPN) consigue pasar de 11.864 votos y 4 concejales, a 16.387 votos y 7 concejales. Aunque Alli no consigue superar en votos al PSOE, la suma de los concejales de laUPN y AP iguala a los concejales socialistas $^{50}$. Esto deja al alcalde Julián Balduz (PSOE) en una precaria situación política, que, después de alguna aproximación a la UPN ${ }^{51}$, resolverá pactando con $\mathrm{HB}^{52}$.

Los resultados de las elecciones autonómicas de 1983 ratifican la posición del PSOE como primera fuerza política, aunque sin mayoría absoluta. En la derecha, la competición entre UPN y AP-PDP resulta claramente favorable a los primeros. En estos comicios, la UPN obtiene más de 60.000 votos (pierde sólo 14.000 respecto a las generales de 1982) y mantiene los 13 escaños de 1979. En cambio, AP-PDP no llega a los 40.000 votos y sólo consigue 8 escaños. La desaparición de la UCD reduce a tres los grandes partidos del subsis-

48. El País, 29 de abril de 1983. En estas elecciones, el partido obtiene la alcaldía en municipios como Azagra, Carcar, Corella, Cintruénigo, Fitero, Sangüesa y Viana (El País, 24 de mayo de 1983).

49. Alli ha sido estrecho colaborador del presidente foral Juan Manuel Arza.

50. Además de PSOE (11), UPN (7) y AP-PDP (4) tienen representación HB (4) y PNV (1).

51. Según El País, «Al parecer, los representantes de UPN habían pedido demasiadas contrapartidas en las negociaciones previas que mantuvieron con los socialistas» (El País, 3 de junio de 1983).

52. El Pais, 3 de junio de 1983. 
tema (PSOE, UPN, HB), pero, como veremos a continuación, no su polarización, las tendencias centrífugas o las dificultades para la gobernabilidad (Llera, 1989).

Las elecciones al Parlamento de Navarra de 1983 abren una profunda crisis institucional que tarda casi un año en cerrarse. De entrada, los seis diputados de HB siguen con la política iniciada en 1981 y se niegan a tomar posesión de sus cargos durante toda la legislatura (Inneraty y Grau, 1998: 405). Ello deja al PNV como el partido clave para decantar las mayorías en un parlamento prácticamente bloqueado por la oposición entre PSN (20 escaños) y la alianza UPN-AP (21 escaños). Las reticencias iniciales de la dirección del PSOE y la división de los votantes dificultan cualquier acuerdo inicial entre el PSN y el $\mathrm{PNV}^{53}$. Gracias a esto, la UPN consigue hacerse con la presidencia del Parlamento, que recae en Baibino Bados ${ }^{54}$.

Dada la situación política, la presidencia del Parlamento desempeña un papel capital en el desarrollo de la crisis. De entrada, Bados propone como candidato a la investidura a José Ángel Zubiaur (UPN). Pero Zubiaur no consigue la mayoría requerida en ninguna de las cuatro votaciones que establece la LORAFNA. Esto facilita el inicio de negociaciones entre el PSOE y el PNV, que no consiguen prosperar ${ }^{55}$. Dadas estas circunstancias, el PSOE renuncia a proponer candidato a la presidencia del Gobierno, lo cual abre un conflicto de interpretación de la ley entre el PSOE y la UPN ${ }^{56}$. Ello propicia que Bados, en una polémica iniciativa, proponga como presidente por nombramiento real al candidato de la UPN (Zubiaur) y no al del PSOE ${ }^{57}$. El Gobierno, en desacuerdo con la iniciativa de Bados, interpone un recurso al Tribunal Constitucional que no se resolverá hasta bien entrado el año $1984^{58}$.

Entretanto, la situación política Navarra se agrava por un cúmulo de circunstancias: es imposible negociar los presupuestos de $1984^{59}$; tampoco en Pamplona el pacto entre el PSOE, HB y el PNV permite aprobar los presupuestos de $1984^{60}$, y, para complicar más las cosas, el Tribunal Supremo se

53. El País, 10 de mayo de 1983 y 29 de mayo de 1986.

54. El País, 9 de junio de 1983.

55. El Pais, 28 de junio de 1983 y 3 de julio de 1983.

56. UPN sostiene que, al renunciar el PSOE a proponer un candidato, el único realmente presentado es el de la UPN. El PSOE interpreta que le corresponde al partido más votado proponer su candidato a presidente, aunque éste no haya propuesto ninguno para la investidura (El País, 21 de agosto de 1983 y 24 de agosto de 1983).

57. Bados viaja personalmente a Mallorca para entregar su propuesta directamente al rey, en vez de hacerlo a través del Ministerio de Administración Territorial (El País, 26 de agosto 1983).

58. El País, 16 de septiembre de 1983. Bados sostiene, entonces, que «el estatuto jurídico de Navarra tiene un carácter jurídico singular y que no es aplicable en este caso el artículo 161.2 de la Constitución que permite al Gobierno interponer recursos contra las decisiones de las comunidades autónomas» (El Pais, 12 de octubre de 1983).

59. El Pais, 19 de septiembre de 1983.

60. El País, 25 de noviembre de 1983. 
pronuncia en contra del acuerdo de la Diputación Foral de 1980, por el que se destituía a Jaime Ignacio del Burgo como presidente ${ }^{61}$.

La sentencia del Tribunal Constitucional es favorable al Gobierno y permite reabrir, de nuevo, el procedimiento de elección del presidente ${ }^{62}$. Pocos días después de hacerse pública la sentencia (y en la recta final de las elecciones al Parlamento Vasco), el PNV se muestra dispuesto a negociar con la UPN o el PSOE su integración en un gobierno de coalición ${ }^{63}$. A las reticencias del PSOE se suma, esta vez, la negativa de Jaime Ignacio del Burgo a formar parte de un gobierno con el PNV ${ }^{64}$. Del Burgo propone, a titulo personal, la abstención de Coalición Popular en Euskadi y del PNV en Navarra. Con la intención, quizás, de dar tiempo a estas negociaciones, Bados propone como candidato al socialista Urralburu. Urralburu no consigue el apoyo de otros partidos en ninguna de las votaciones, lo que permite oficializar los contactos entre PNV, UPN y Coalición Popular. Con todo, el acuerdo no puede cerrarse por la posición de Del Burgo ${ }^{65}$, pero, también, por problemas internos dentro de la UPN y el PNV. En la UPN, los problemas parecen afectar tanto a la aceptación interna de Juan Cruz Alli como candidato a la investidura, como a las reticencias de una parte del partido a las negociaciones con el $\mathrm{PNV}^{66}$. En el PNV, la crisis es mucho más compleja y terminará, meses más tarde, confluyendo con la escisión de Garaikoetxea y la formación de Eusko Alkartasuna (EA). En un último gesto, Coalición Popular decide presentar, con el apoyo de la UPN, a José Luis Monge como candidato a la presidencia. De todos modos, éste tampoco obtiene los votos necesarios para la investidura, por lo que es finalmente Gabriel Urralburu (PSN) quien, casi un año después de las elecciones, obtiene la presidencia del gobierno navarro. La distancia entre el PSOE y la UPN no impiden el acuerdo de estos dos partidos en muchos de los grandes temas de la legislatura ${ }^{67}$.

61. El TS entiende que no puede aplicarse la Ley de elecciones locales que permitió la moción de censura (El País, 9 de noviembre de 1983). Se da la circunstancia, además, que, en estos momentos, Del Burgo ha presentado su renuncia a continuar como diputado foral para poder acceder al cargo de vicepresidente primero del Parlamento Navarro (El País, 18 de junio de 1983).

62. Según el TC, el proceso se debe retrotraer al momento inmediatamente posterior a la celebración de la cuarta votación en el Parlamento navarro. El presidente debe proponer a un nuevo candidato y, si éste no obtuviese la mayoría absoluta, deberá proponer el nombramiento del representante del partido político que cuente con mayor número de escaños $(E l$ Pais, 7 de febrero de 1984).

63. El Pais, 11 de febrero de 1984.

64. El País, 20 de febrero de 1984.

65. «Dada la intransigencia del presidente del PDP en Navarra [...] a formar parte de un Ejecutivo de coalición en el que figuraría también el PNV se decidió de forma unánime romper las conversaciones que se venían manteniendo desde hace varias semanas" (El País, 23 de marzo de 1984).

66. Pese a que Alli es el candidato que cuenta con el apoyo sin reservas de Coalición Popular $(E l$ País, 11 de febrero de 1984), su propuesta parece no llegar a confirmarse definitivamente por los órganos directivos del partido. Del mismo modo, el pacto con el PNV es visto con reservas por algunos sectores del partido (El País, 26 de marzo de 1984).

67. Destaca, entre ellos, la aprobación, el 12 de junio de 1985, del reglamento definitivo del Parlamento de Navarra (Ramos y Innerarity, 1998: 405). 


\section{La transformación del modelo originario: de la integración de la UCD al pacto entre la UPN y el PP (1985-1991)}

El Segundo Congreso de la UPN (2 y 3 de febrero de 1985) se celebra en un clima de abierta división interna. La crisis parece empezar días antes del congreso, cuando aparece, en el Diario de Navarra, una declaración política firmada por Juan Cruz Alli y otras seis personas, donde se hacen públicas las diferencias con la dirección del partido. Las discrepancias de este grupo (autodenominado liberal o renovador) tienen como base la posición respecto al País Vasco (donde dan por superado el problema de la integración ${ }^{68}$ ) y la necesidad de renovar la dirección del partido para facilitar una alternativa de centro-derecha al PSN ${ }^{69}$. Ambos puntos contradicen aspectos importantes de la ponencia ideológica elaborada por Jesús Aizpún ${ }^{70}$. Alli y sus seguidores presentan también una enmienda a la ponencia estatutaria, para que la elección del Comité Ejecutivo sea por primera vez por listas abiertas.

Más allá de estas diferencias entorno a la línea política, las raíces del conflicto entre estos dos grupos deben situarse, sin duda, en la integración en el partido (entre 1982 y 1983) de una parte substancial de los cuadros de la extinta $\mathrm{UCD}^{71}$. La incorporación en masa de estos dirigentes permite a la UPN mejorar muy rapidamente su implantación territorial, pero también favorece que aumenten las fricciones con el núcleo que dirige el partido desde su fundación ${ }^{72}$. Ello se debe, fundamentalmente, a dos razones: a) La limitada dis-

68. Poco antes del Congreso, Alli dirá al respecto «Este punto fue el origen del nacimiento de UPN para atajar el entreguismo de UCD, pero ahora está formal y materialmente zanjado. No hay riesgo de absorción. Ahora lo que hay que hacer es mejorar las condiciones materiales y culturales de los navarros para que ningún sector se sienta tentado a intentar las vías de integración previstas porque en el País Vasco se viva mejor o se respete más la cultura de un sector de los navarros que son los euskaldunes» (Diario de Navarra, 2 de febrero de 1985: 29).

69. Según Alli «Entendemos que [UPN] ha de articularse de tal modo que sea el aglutinante de todsa las fuerzas de centro-derecha [...] ello exige una capacidad de negociación [que] no es posible con los actuales dirigentes, porque cada vez que se sientan en una mesa saltan chispas» (Diario de Navarra, 2 de febrero de 1985: 29).

70. Aizpún sostiene sobre la integración: «Se dice que se trata de un problema ya superado y que debe olvidarse ya. En esto no estamos de acuerdo. Mientras haya una Comunidad como es Euskadi con firme propósito de anexionar Navarra, mientras haya partidos nacionalistas y abertzales con un planteamiento continuo y permanente de constituir el ente político de Euzkadi con inclusión de Navarra, el problema sigue vivo». Sobre los pactos con otros partidos de derecha «Nuestra afiliación política y el partido se definen de centro-derecha. No con vocación de partido bisagra, sino con vocación de partido mayoritario, de alternativa de gobierno" (Diario de Navarra, 2 de febrero de 1985: 29).

71. «La asamblea de afiliados celebrada en diciembre de 1982 marcó un antes y un después en la labor de implantación del partido. Se puede decir que, a partir de ese momento, UPN se enfundó el traje de faena para ampliar su base social y hacerse un hueco en Navarra» (Por Navarra, febrero de 2004: 10).

72. Pese a que no hay datos sobre los cambios en la implantación municipal, el partido pasa (según sus propios datos) de 400 miembros en 1981 a 1.600 en 1985. 
posición de esta élite a integrar a estos nuevos dirigentes (con excepciones como las de R. Gurrea) parece ser una de las causas del conflicto, y b) la otra (mucho menos explícita) conviene buscarla en la bicefalia real que se genera entre Aizpún (líder del partido y del Comité Ejecutivo) y Alli (líder del grupo parlamentario en el Parlamento de Navarra). Por lo demás, la existencia de dos líderes con visiones bastante distintas de la política comporta, más temprano que tarde, su enfrentamiento abierto por el control del partido.

La nota distintiva de la crisis que se abre en el Segundo Congreso de 1985 es que tarda diez años en resolverse. Ello tiene importantes consecuencias en el modelo organizativo del partido. La primera y más evidente es la división de su coalición dominante. Con todo, los arreglos organizativos derivados de este Segundo Congreso ${ }^{73}$ y el respeto a la frecuencia de los congresos (cada cuatro años) permiten que, sólo ocasionalmente, la división se traduzca en inestabilidad. Más complejo es el equilibrio de poder entre quienes controlan el grupo parlamentario y quienes controlan el Comité Ejecutivo. La relación de fuerzas entre ambos variará a lo largo de los años.

El Congreso de 1985 se salda con la victoria inicial de Alli, al conseguir imponer a su candidato a la presidencia del congreso y abrir el sistema de elección del Comité Ejecutivo ${ }^{74}$. Alli consigue obtener, además, un excelente resultado, al quedar sólo a diecisiete votos de Aizpún en su disputa por la presidencia del partido ${ }^{75}$. Con todo, Aizpún consigue mantener a sus hombres en los principales cargos de la formación y una holgada mayoría en el Comité Ejecutivo (tabla 4) ${ }^{76}$.

La crisis continúa después del congreso por la decisión del Comité Ejecutivo de la UPN de abrir un expediente a tres diputados: Juan Cruz Alli, Albito Viguria (portavoz de la UPN en el Parlamento) y Antonio Andía Ustárroz, por sus declaraciones sobre la situación interna del partido. Viguria y Andía abandonan por entonces la UPN ${ }^{77}$, pero ello no termina con los ajustes de cuentas internos, sobre todo a raíz de una polémica sobre informes elaborados por el presidente del Parlamento a miembros del partido ${ }^{78}$. La división es

73. La más importante es que en vez de votar una sola lista (con la atribución de cargos) se vota individualmente al presidente, a los dos vicepresidentes y al secretario y, en lista abierta, a los once vocales del Comité Ejecutivo. Conviene señalar que el Comité Ejecutivo pasa de once a quince miembros y que el Consejo Regional pasa de treinta a cincuenta (sin incluir a los miembros del Comité Ejecutivo).

74. Diario de Navarra, 3 de febrero de 1985: 1.

75. Diario de Navarra, 4 de febrero de 1985: 1.

76. Aizpún sólo consigue obtener dos de los once vocales y ninguno de los cargos más directamente implicados en el día a día del partido (Diario de Navarra, 4 de febrero de 1985: 35)

77. El País, 15 de marzo de 1981.

78. Bados habría pagado con fondos públicos diversos informes encargados al renovador Luis Fernando Medrano y a los oficialistas Rafael Gurrea y Pedro Eza (El País, 22 de mayo de 1985). Ello abre una polémica en la que el PNV llega a pedir el cese del presidente del Parlamento (El País, 23 de septiembre de 1985). A finales de 1986, un instructor del Tribunal de Cuentas comprueba irregularidades por valor de unos $24.300 €$ (El País, 26 de noviembre de 1986). 
Tabla 4. Peso de cada facción dentro del Comité Ejecutivo (1981-1989)

\begin{tabular}{|c|c|c|c|c|c|}
\hline & \multirow{2}{*}{$\begin{array}{c}1981 \\
\text { Aizpún }\end{array}$} & \multicolumn{2}{|c|}{1985} & \multicolumn{2}{|c|}{1989} \\
\hline & & Aizpún & Alli & Aizpún & Alli \\
\hline Presidente & 1 & 1 & 0 & 1 & - \\
\hline Vicepresidente & 1 & 2 & 0 & 0 & 1 \\
\hline Secretario general & 1 & 1 & 0 & 1 & - \\
\hline Vicesecretario & - & - & - & 1 & - \\
\hline Vocales & 8 & 9 & 2 & 2 & 9 \\
\hline
\end{tabular}

Fuente: elaboración propia.

visible también en la elaboración de las candidaturas, que desde entonces se elaboran teniendo en cuenta criterios faccionales (tabla 5).

Las elecciones generales de 1986 vienen precedidas por el éxito que, en Navarra, obtiene el no en el referéndum de la OTAN. La posición oficial de la UPN en el referéndum consiste en dar libertad de voto a sus afiliados, pero recomendando la abstención ${ }^{79}$. Aun así, el éxito del no difícilmente puede explicarse sin el apoyo de amplios sectores de la UPN ${ }^{80}$.

El resultado del referéndum no tiene una traducción directa en las elecciones generales, pero sí consigue erosionar, en parte, el voto socialista. La repetición de la alianza entre UPN y AP-PDP que ya se produjo en 1982 produce un balance excepcional. La UPN obtiene casi 81.000 votos, los mejores resultados electorales desde su creación y casi 20.000 más que en 1982 (tabla 6). Ello se traduce en un escaño en el Congreso para los oficialistas Aizpún y L. F. Medrano, y en la elección de Jaime Ignacio del Burgo (AP-PDP) como senador.

Las elecciones autonómicas y municipales de 1987 están marcadas, sin duda, por la nueva recomposición en el sistema de partidos que sigue a la ruptura entre Coalición Popular y el PDP. En Navarra, esta ruptura tiene importantes consecuencias, debido a que el principal líder de la alianza AP-PDP es Jaime Ignacio del Burgo, del PDP. Así pues, en estas elecciones se presentan, además de la UPN, el CDS, AP y la recién creada Unión de Demócratas Forales $\left(\mathrm{UDF}^{81}\right)$. UPN presenta al renovador Juan Cruz Alli como candidato a la presidencia, con una lista claramente elaborada con criterios faccionales (tabla 5).

Los resultados de las elecciones municipales muestran la implantación del PSN, primera fuerza política en votos y en concejales. Para la UPN, los resultados son buenos, debido, fundamentalmente, a su victoria electoral en la capi-

79. Por Navarra, febrero de 2004: 17.

80. En un reportaje de El País, un entrevistado da una explicación bastante plausible de lo sucedido «ha debido influir, desde luego, un voto de derecha que en este caso se ha unido al voto abertzale y al pacifista" (El País, 27 de marzo de 1986).

81. UDF es una alianza entre PDP dirigido por Del Burgo y el Partido Liberal (El Pais, 4 de junio de 1987). Pasadas las elecciones, Del Burgo renunciará a su escaño para seguir de Senador (El Pais, 28 de junio de 1987). 
Tabla 5. Peso de cada facción en el Paralmento de Navarra y en las Cortes Generales

\begin{tabular}{lccccc}
\hline & $1982 \mathrm{G}$ & $1983 \mathrm{PN}$ & $1986 \mathrm{G}$ & $1987 \mathrm{PN}$ & $1989 \mathrm{G}$ \\
\hline Aizpún & $2+1(\mathrm{~S})$ & 13 & 2 & 7 & $1+1(\mathrm{~S})$ \\
Alli & - & - & 0 & 7 & $1+2(\mathrm{~S})$ \\
\hline
\end{tabular}

Fuente: elaboración propia.

Siglas: S: Senado; PN: Parlamento de Navarra; G: elecciones generales.

tal, Pamplona. Pese a mantener los 7 concejales de 1987, el oficialista Chourraut consigue pasar de los 16.387 votos de 1983 a los 21.335 . Ello permite que UPN se sitúe por primera vez por delante del PSN en Pamplona y, finalmente, que Chourraut obtenga la alcaldía ${ }^{82}$.

Los resultados de las elecciones al Parlamento Navarro de 1987 sirven para reflejar, sobre todo, la extrema fragmentación del sistema de partidos (Llera, 1989: 516 y s.) (tabla 6). Ocho partidos obtienen representación parlamentaria y ninguno de ellos consigue la mayoría suficiente para gobernar. El PSOE es, de nuevo, el partido con más votos y escaños, pero con un importante retroceso respecto a comicios anteriores. En el caso de la UPN, Alli obtiene casi 70.000 votos, lo que representa sólo 10.000 votos menos que los conseguidos por la coalición entre UPN y AP-PDP en las generales de 1986. Dada la fragmentación de los partidos de derechas, el resultado de Alli es, sin duda, un éxito $^{83}$. Ello impulsa a la UPN, como ya hizo en 1983, a buscar alianzas para conseguir la presidencia.

Como ya sucedió en 1983, la falta de mayorías complica substancialmente el proceso de investidura ${ }^{84}$. Ello es especialmente visible en la elección del presidente de la cámara, que, finalmente, recae en Javier Gómara ${ }^{85}$. Gómara designa al socialista Urralburu como el primer candidato a la presidencia del Gobierno Foral. Con todo, Urralburu no es capaz de conseguir el apoyo de ningún otro grupo ${ }^{86}$, lo que permite que también Juan Cruz Alli sea propuesto como candidato $^{87}$. Pese al apoyo de AP y UDF, Alli no consigue, sin embargo, atraerse el apoyo del CDS, y su candidatura es también rechazada ${ }^{88}$. Ello faci-

82. Chourraut es elegido alcalde por ser el candidato del partido más votado. En las votaciones, AP y UDF optan por la abstención, mientras que el CDS se vota a si mismo (El País, 1 de julio de 1987).

83. Los resultados muestran, a su vez, que una alianza entre todos ellos permitiría obtener unos resultados cercanos a los 100.000 votos: $69.419(\mathrm{UPN})+17.663(\mathrm{UDF})+11.985(\mathrm{AP})=$ 99.067 votos.

84. Por si fuera poco, en esta legislatura, HB decide regresar de nuevo al Parlamento navarro, del que estuvo ausente desde 1981.

85. Gómara sale elegido tras la tercera votación por ser el candidato de más edad (El País, 5 de julio de 1987).

86. El País, 6 de agosto de 1987.

87. El País, 11 de agosto de 1987.

88. Desde las primeras conversaciones entre UPN, AP, UDF y CDS, la posición del CDS se inclina hacia la abstención (El País, 6 de agosto 1987, 21 de agsto de 1987 y 27 de agosto de 1987). 
lita que Urralburu resulte reelegido presidente, por ser el candidato de la lista más votada ${ }^{89}$. Urralburu continuará también en esta legislatura con su política de acuerdos con la UPN. Como contrapartida, el PSOE facilitará a la UPN apoyo en Pamplona. Las diferencias entre ambos partidos llegaran en materia de fiscalidad, pero, sobre todo, por las relaciones con el País Vasco: la UPN se opone a la creación de un órgano común de cooperación con el Gobierno de Euskadi y a firmar el pacto de Ajuria Enea contra la violencia ${ }^{90}$. En cambio, sí acepta participar en el Acuerdo por la paz y la tolerancia firmado por las fuerzas políticas navarras en octubre de $1988^{91}$.

El Tercer Congreso de la UPN se celebra el 28 y 29 de enero de 1989, en un contexto marcado por las negociaciones entre el Gobierno y ETA en Argel y por la refundación de AP en el Partido Popular. La negociación con ETA provoca, de hecho, discrepancias entre oficialistas y renovadores antes y después del congreso. En 1987, por ejemplo, Alli llega a afirmar, en su discurso como candidato a la presidencia, la posibilidad de colaborar con el País Vasco. A ello debe sumarse, pocas semanas antes del congreso, unas declaraciones en Egin favorables a la negociación con ETA dentro de los límites constituciona$\operatorname{les}^{92}$. La intervención inicial de Aizpún en el congreso fija claramente la línea política en ambas cuestiones: su confianza en que Navarra no estará involucrada en las negociaciones entre el Gobierno y ETA ${ }^{93}$ y su disposición a negociar acuerdos electorales con el PP (sobre todo en las elecciones forales), aunque excluyendo la fusión ${ }^{94}$. El silencio del sector renovador entorno a la línea política marcada por Aizpún facilita que toda la atención se concentre en la disputa por el control del Comité Ejecutivo y del Consejo Regional. Esta vez, la habilidad táctica de los renovadores y los problemas internos dentro de los oficialistas favorecen un substancial cambio de fuerzas en la composición de los principales órganos del partido. A diferencia de 1985, en que Alli disputó

89. El País, 2 de octubre de 1987.

90. Pese al apoyo de la mayoría de partidos españoles, UPN (como el Partido Aragonés Regionalista y Unió Valenciana) no firma el pacto. La posición de Aizpún es conocida «se aprovecha la ocasión del documento para mantener viva la expectativa de la anexión de Navarra a la comunidad vasca» (El País, 13 de mayo de 1988).

91. El pacto se firma el 7 de octubre de 1988 por parte de PSN-PSOE, UPN, CDS, Euskadiko Ezkerra, PL y PP (El Pais, 28 de febrero de 1989).

92. El País, 26 de marzo de 1989. Estas declaraciones de Alli contrastan con la posición del partido contraria a firmar el pacto de Ajuria Enea o el pacto de Madrid.

93. "Aizpún afirma su confianza en Urralburu y Corcuera sobre la ausencia de Navarra en las conversaciones de Argel» (Diario de Navarra, 29 de enero de 1989: 30). Aizpún no muestra mucho entusiasmo ni sobre los acuerdos parlamentarios (Ajuria Enea, Madrid, etc.), ni sobre las negociaciones (Diario de Navarra, 29 de enero de 1989: 30).

94. Aizpún sostiene que «UPN no está en la bancarrota ni en quiebra y no necesitamos una oportunidad para vivir. Nuestro partido es como una empresa que paga dividendos y por eso no está dispuesta a fusionarse [...] UPN debía estar dispuesta a estudiar sistemas de colaboración que redundaran en beneficio de una alternativa del PSOE, pero siempre que en esa colaboración el Partido Popular se comprometiera con UPN para las elecciones forales» (Diario de Navarra, 29 de enero de 1989: 30). 
Tabla 6. Resultados obtenidos en el Congreso de los Diputados y en el Parlamento Navarro (1986-1989)

\begin{tabular}{|c|c|c|c|c|c|c|c|c|c|c|c|c|}
\hline \multirow[b]{2}{*}{ Partido } & \multicolumn{3}{|c|}{$1986 \mathrm{G}$} & \multicolumn{3}{|c|}{$1987 \mathrm{PN}$} & \multicolumn{3}{|c|}{$1987 \mathrm{M}$} & \multicolumn{3}{|c|}{1989} \\
\hline & Votos & $\%$ & $\mathrm{E}$ & Votos & $\%$ & $\bar{E}$ & Votos & $\%$ & $\mathrm{C}$ & Votos & $\%$ & $\mathrm{E}$ \\
\hline PSN & 97.010 & 35,5 & 2 & 78.453 & 28,1 & 15 & 64.465 & 23,3 & 272 & 86.677 & 31,2 & 2 \\
\hline $\mathrm{HB}$ & 37.998 & 13,9 & 1 & 38.138 & 13,7 & 7 & 33.330 & 12,1 & 141 & 30.632 & 11,0 & 0 \\
\hline CDS & 26.106 & 9,56 & 0 & 21.022 & 7,5 & 4 & 15.034 & 5,4 & 35 & 19.538 & 7,0 & 0 \\
\hline UDF & - & - & - & 17.663 & 6,3 & 3 & 7.412 & 2,7 & 12 & - & - & - \\
\hline $\mathrm{IU}$ & 4.244 & 1,5 & 0 & 3.802 & 1,4 & 0 & 3.379 & 1,2 & 7 & 15.979 & 5,8 & 0 \\
\hline $\mathrm{AP}$ & - & - & - & 11.985 & 4,3 & 2 & 7.230 & 2,6 & 15 & - & - & - \\
\hline $\mathrm{EE}$ & 7.645 & 2,8 & 0 & 9.618 & 3,4 & 1 & 5.557 & 2,0 & 2 & 7.949 & 2,9 & 0 \\
\hline PNV & 4.9352 & 1,8 & 0 & 3.071 & 1,1 & 0 & 1.949 & 0,7 & 6 & 2.562 & 0,9 & 0 \\
\hline
\end{tabular}

Fuente: Ministerio del Interior y Parlamento de Navarra.

En negrita, el partido más votado en cada elección. E: Escaños. C: Concejales.

Se excluyen aquellos partidos que, pese a obtener concejales, no obtienen representación en el Congreso o en el Parlamento Navarro.

1.UPN-AP-PL.

2. UPN-PP.

Siglas: PSN-PSOE: Partido Socialista de Navarra-Partido Socialista Obrero Español; UPN: Unión del Pueblo Navarro; HB: Herri Batasuna; CDS: Centro Democrático y Social; EA: Eusko Alkartasuna; UDF: Unión Demócratas Forales (PDF-PDP-PL); IU: Izquierda Unida; AP: Alianza Popular; EE:

Euskadiko Ezkerra; PNV: Partido Nacionalista Vasco. 
a Aizpún la presidencia del partido, esta vez los renovadores optan por no competir en ninguno de los principales cargos ejecutivos (presidencia, secretaría general, vicesecretaría). En cambio, concentran su energía en conseguir la vicepresidencia ${ }^{95}$ y en presentar una lista cerrada para obtener la mayoría en el Comité Ejecutivo y en el Consejo Regional ${ }^{96}$. Además de su maquiavelismo, los renovadores explotan hábilmente los recelos de buena parte del partido hacia la antigua dirección ${ }^{97}$. La táctica de los renovadores se ve favorecida por los enfrentamientos dentro del núcleo que hasta entonces ha dirigido el partido. Ello es claramente visible en los desacuerdos entorno al papel del antiguo presidente Gómara en la ejecutiva ${ }^{98}$ y en la presentación de cuatro candidatos oficialistas a la vicepresidencia ${ }^{99}$.

El resultado del congreso es un rotundo triunfo del sector renovador. Como estaba previsto, los oficialistas consiguen los principales cargos unipersonales de la ejecutiva (Aizpún, presidente; Gurrea, secretario general, y Eza, vicesecretario), pero los renovadores sitúan a Miguel Sanz en la vicepresidencia, obtienen nueve de los once vocales del Comité Ejecutivo (tabla 4) y consiguen una importante mayoría en el Consejo Regional ${ }^{100}$.

La coincidencia del Tercer Congreso con el décimo aniversario de la fundación del partido representa una buena oportunidad para mostrar las prin-

95. Pese a que la vicepresidencia no tiene funciones muy definidas en los estatutos, durante el Congreso no deja de repetirse su importancia, dado que Aizpún está buena parte de la semana en el Congreso de los Diputados. Curiosamente, los renovadores deciden no presentar a Alli a este cargo, sino a un joven alcalde: Miguel Sanz. Alli se presenta como vocal del Comité Ejecutivo.

96. Diario de Navarra, 30 de enero de 1989: 45.

97. Alli afirma «la afiliación de UPN no tragó el comportamiento de los anteriores miembros del Ejecutivo cuando redactaron las listas electorales. Ellos mismos se votaron y se colocaron en los puestos de salida. Eso tuvo una lectura nefasta. [...] Hace ya tiempo que detectamos que el ambiente se iba caldeando de cara al III Congreso. Era un tema casi obsesivo. Había ganas de cambio» (Diario de Navarra, 30 de enero de 1989: 45).

98. Gómara impulsa la presentación de una enmienda a los estatutos para que el último presidente del partido pueda integrarse como miembro nato en la ejecutiva. A propuesta de sus compañeros de facción, la enmienda es aprobada, pero con una interpretación que excluye a Gómara de la ejecutiva. Como muestra de desafío, Gómara presenta entonces su candidatura a la presidencia del partido, que más tarde retira para presentarse a la vicepresidencia.

99. La lucha inicial por la vicepresidencia está concentrada en Bados (oficialista) y Sanz (renovador) (Diario de Navarra, 28 de enero de 1989: 29). Los desacuerdos internos favorecen que también Gómara (antiguo presidente) y Medrano (diputado al Congreso) opten al cargo. A ello se suma, en el último instante, la candidatura de Del Castillo, que, pese a estar inicialmente vinculada al sector oficialista, parece haber llegado a algún tipo de acuerdo con Alli. Como él mismo afirma «he luchado desde hace quince días para que [Alli] estuviese en la vicepresidencia por entender que era el más preparado" (Diario de Navarra, 30 de enero de 1989: 44). Su candidatura «no tenía otro objeto que atraer votos para que no fueran hacia los rivales de Miguel Sanz. La jugada salió bien» (Diario de Navarra, 30 de enero de 1989: 45). Pese a que Medrano retira en el último momento su candidatura, los votos de Del Castillo quitan apoyos a Gómara y a Bados.

100. Diario de Navarra, 30 de enero de 1989: 45. 
cipales características de su estructura y de su funcionamiento durante los años ochenta (cuadro 1). Los principales rasgos son: su notable estabilidad organizativa (según se regula en los estatutos) ${ }^{101}$, la débil articulación de su estructura y el importante grado de centralización.

La afiliación a la UPN es directa desde sus orígenes y requiere del aval de dos adherentes. Los miembros se agrupan territorialmente en comités locales de los que muy poco se dice sobre sus funciones y su organización ${ }^{102}$. En cualquier caso, como también pasa en los órganos centrales del partido, el peso de los electos locales en ellos es muy importante ${ }^{103}$. Por encima de los comités locales, están los comités de merindad. De todas maneras, éstos no tienen un papel claramente delimitado. Su única función clara es designar a algunos miembros del Consejo Regional del partido ${ }^{104}$. Pese al progresivo aumento de miembros a partir de la desintegración de la UCD, la articulación del partido a nivel local no mejora substancialmente durante los años ochenta, y la debilidad es su principal característica. Una vez al año, el partido celebra su asamblea abierta a todos los miembros. En estas asambleas, se discuten las directrices principales de su línea política para el año siguiente. Cada cuatro años, la asamblea se constituye en congreso para deliberar sobre la ideología, la línea política y algunas políticas sectoriales, pero, sobre todo, para elegir a los miembros del Comité Ejecutivo y (de parte) del Consejo Regional.

El carácter altamente centralizado del partido es visible por la atención que reciben los órganos centrales, especialmente el Comité Ejecutivo. Este órgano es el encargado de controlar el día a día del congreso: aprobar las solicitudes de afiliación; las listas electorales; la constitución (o disolución) de los comités locales, los comités de merindad y los órganos sectoriales; la actuación de los

101. Ello contrasta, sin embargo, con los importantes cambios en el mapa de poder organizativo, especialmente por lo que se refiere al poder de los parlamentarios (Panebianco, 1990).

102. Éstos son obligatorios en ciudades de más de tres mil habitantes, pero no en el resto de localidades. En un informe aprobado en el Tercer Congreso, se afirma «en Navarra existen básicamente del orden de 50 localidades con una población que permite que la acción social y política tenga repercusión [...] con ellas coincide, en un $90 \%$, nuestra actual estructura territorial. Si bien nuestra afiliación procede de más de ciento cincuenta localidades, en muchos casos, las posibilidades de actuación se reducen a colaborar con los grupos municipales y a mantener contactos periódicos con los afiliados y simpatizantes» (UPN, 1989: 54). Respecto a sus funciones, no está clara ni su autonomía ni el papel que éstos tienen en la designación de los candidatos para las elecciones municipales.

103. Los representantes locales «son miembros natos de los comités locales y tienen, también como miembros natos con plenos derechos, una importante representación en el Consejo Regional»(UPN, 1989: 56). Ello parece generar tensiones, pues «debe avanzarse en la comprensión de las relaciones que deben existir entre los Comités Locales y los Grupos Municipales» (UPN, 1989: 56).

104. En una provincia de la extensión de Navarra, la constitución de órganos territoriales intermedios no parece tener mucho sentido y menos todavía cuando su existencia no tiene un equivalente en términos institucionales. Todo indica que los comités de merindad se crearon para las primeras elecciones al Parlamento Foral (1979), donde sí tenían un papel asignado por la normativa electoral (Real Decreto Paccionado 121/1979). Con la aprobación de la LORAFNA, las merindades dejan de tener una función específica. 
respectivos grupos parlamentarios; la ejecución de los presupuestos ${ }^{105}$; etc. El amplio poder formal del Comité Ejecutivo difícilmente puede ser equilibrado por los órganos encargados de su control: el Comité de Cuentas, el Comité de Disciplina y el Consejo Regional. El principal de estos órganos es el Consejo Regional. Con todo, éste se reúne poco (bimensualmente) y su función parece ser más de veto que de impulso. Su composición es progresivamente monopolizada por los cargos públicos del partido (cuadro 1).

La concentración de poder en el Comité Ejecutivo debe ser matizada, de todos modos, por dos fenómenos que tienen que ver con los cambios dentro del mapa de poder organizativo (no con disposiciones formales):

a) El primero es, sin duda, la creciente influencia y protagonismo de los cargos públicos en el aparato del partido. Sin duda, ésta es una tendencia ya presente desde la fundación del partido, pero acentuada con el acceso de la UPN a las instituciones. Ello es visible con el aumento del peso de los parlamentarios en la ejecutiva o con las disposiciones de los estatutos referentes a los miembros natos del consejo territorial (cuadro 1).

b) El segundo tiene que ver con el faccionalismo que divide al partido desde 1985.

Ambos fenómenos permiten matizar el grado de centralización y poder del Comité Ejecutivo respecto al resto de órganos de la organización.

Como ya sucedió en el congreso anterior, la lucha entre facciones se reproduce, de modo más o menos sutil, en buena parte de las decisiones tomadas durante los meses posteriores al congreso de 1989. Pese a la disposición inicial de la UPN de formar parte de la Federación de Partidos Regionales ${ }^{106}$, posteriores negociaciones entre Aizpún y Fraga parecen decantar un acuerdo de la UPN con el $\mathrm{PP}^{107}$. Este acuerdo parece extenderse a las elecciones generales de $1989^{108}$. Con todo, en estas elecciones, los renovadores consiguen imponer a sus candidatos (Gayarre para el Congreso y Del Castillo e Iribas para el Senado) en un terreno que hasta entonces era exclusivo de los oficialistas.

En las elecciones generales de 1989, el pacto entre el PP y la UPN permite situar a esta coalición como la primera fuerza política de Navarra. En el Congreso, la lista liderada por Aizpún obtiene más de 92.000 votos. En el Senado, el renovador Javier del Castillo consigue más de 89.000 votos. Ello permite obtener tres escaños en el Congreso (Aizpún y Gayarre por la UPN; Del Burgo por el PP)

105. Según se informa en el Tercer Congreso, en 1988 los ingresos del partido ascendieron aproximadamente a 300.000 euros (Diario de Navarra, 30 de enero de 1989: 44).

106. El País, 16 de enero de 1989 y 5 de febrero de 1989.

107. Aizpún negocia a principios de febrero de 1989 la coalición con el PP en las europeas. En estas negociaciones, Fraga se muestra dispuesto a apoyar la candidatura de la UPN en las próximas autonómicas (El País, 7 de febrero de 1989). En las elecciones al Parlamento Europeo, el PP obtiene alrededor de 80.000 votos.

108. El acuerdo electoral entre la UPN y el PP se firma en el mes de septiembre de 1989 (El País, 9 de septiembre de 1989). 


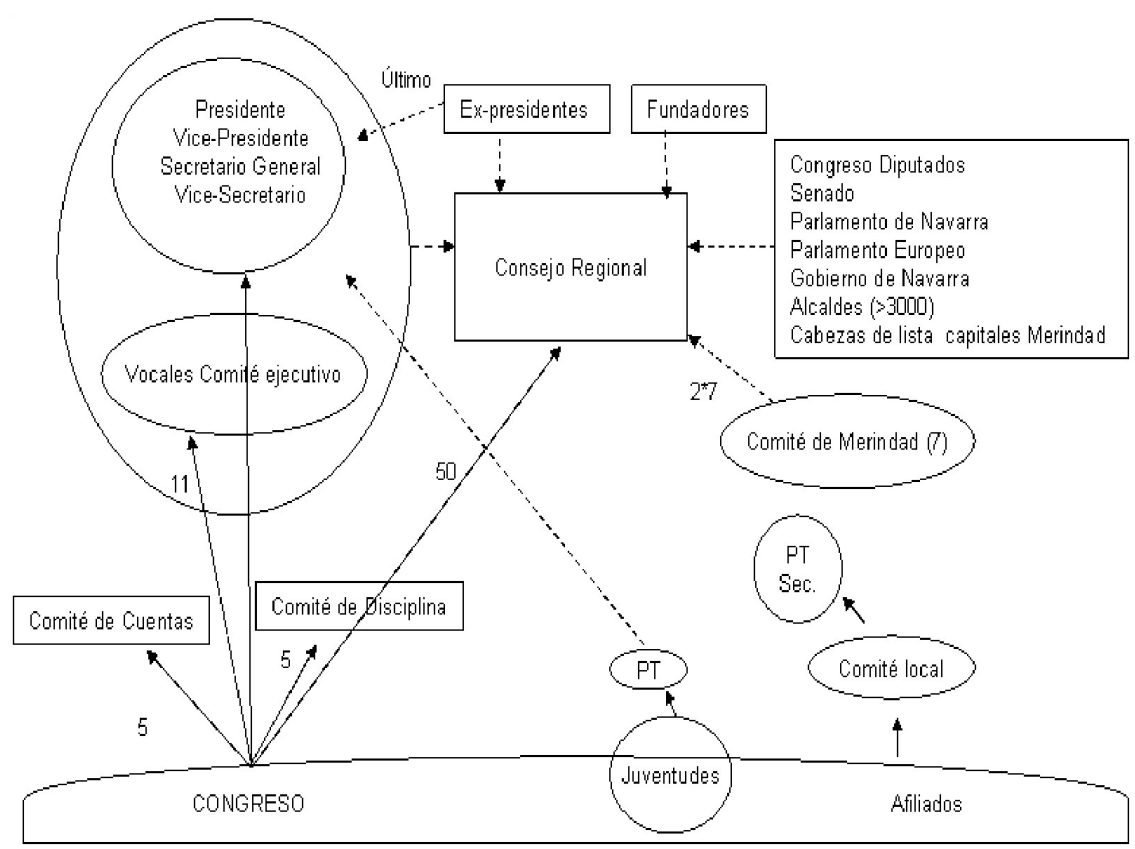

Cuadro 1. Organización del partido a partir de los estatutos (1989)

Fuente: elaboración propia a partir de los estatutos de 1989 (UPN, 1989).

Los rectángulos representan órganos de control; las esferas, órganos ejecutivos. Las líneas continuas indican elección; las discontinuas, la incorporación como miembros natos.

y tres escaños en el Senado (dos para los renovadores Del Castillo e Iribas y uno para el oficialista Viñes). El éxito de estos resultados y la consolidación del PP de José M. Aznar como alternativa política al PSOE favorecen que ambos partidos decidan estrechar su colaboración en el futuro. Ésta llegará a finales de 1990 con la propuesta de la alianza permanente entre ambos partidos.

\section{Conclusiones}

El caso de la Unión del Pueblo Navarro ha demostrado ser fundamentalmente distinto al de la mayoría de partidos regionalistas europeos que tienden a desarrollarse durante años como partidos extraparlamentarios y a organizarse entorno a estructuras típicas de los partidos de masas. Como este artículo ha intentado señalar, la UPN se estructura desde sus orígenes como un partido muy próximo al modelo de partido electoral professional o catch-all. Pese a que también comparte algunas características con el new cadre party, su debilidad organizativa no permite clasificarlo como tal, pues las fuentes de financiación de la UPN difícilmente pueden proceder de los miembros o tener un carácter mixto. Como en muchos de los partidos españoles, son esencialmente públicas. 
Algunas de las principales características que inicialmente definen a la UPN son la ausencia de instituciones patrocinadoras y su lento y difícil crecimiento territorial (hasta la desaparición de la UCD). Con todo, el fulgurante ascenso electoral del partido se debe, en buena medida, al liderazgo de su líder, Jesús Aizpún, y a su habilidad para explotar los temores que suscita, en una parte de la población, la posible integración de Navarra al País Vasco. El éxito de este discurso permitirá al partido consolidarse desde su nacimiento como una importante fuerza parlamentaria. El éxito electoral permitirá recibir una buena parte del dinero de funcionamiento del partido, que, en su día a día, se organizará sobre la base de sus cargos públicos.

La desintegración de la UCD y la integración en el partido de buena parte de sus cuadros permite ampliar la base territorial en muy poco tiempo, aumentar substancialmente el número de votantes y empezar a pensar en el acceso al gobierno. Pero ello abre, también, una etapa de división dentro de la dirección. Ello es posible, en parte, por el carácter multinivel de la representación institucional del partido. La creación de diversas arenas de poder y sus efectos en la evolución de los partidos ha sido poco explorada por la teoría. El caso de la UPN parece mostrar cómo ello genera una bicefalia dentro del partido entre Aizpún, el líder en el Congreso y principal responsable de la organización, y Alli, el líder de los diputados en el Parlamento de Navarra. Con todo, ni siquiera la división faccional que se abre a partir de 1985 puede alternar buena parte de las características originarias del partido. Éste sigue altamente centralizado, débilmente articulado y con un peso muy notable de los políticos profesionales en sus órganos de dirección.

\section{Bibliografía}

AAVV (1994). El Parlamento Foral de Navarra (1979-1983). Pamplona: Servicio de Publicaciones del Parlamento de Navarra.

Bermejo, Moisés; Díez, Pablo (1990). Crónica del Parlamento de Navarra (19791989). Pamplona: Servicio de Publicaciones del Parlamento de Navarra.

BugajSKI, Janusz (2002). Political Parties of Eastern Europe: A Guide to Politics in the PostCommunist Era. Armonk: N.Y.

CHUECA, Josu (2002). «Puntos y contrapuntos para la historia política de Navarra». En: LANA, Miguel A. (coord.). En torno a la Navarra del siglo XX. Veintiún reflexiones acerca de sociedad, economía e historia. Pamplona: Universidad Pública de Navarra, p. 361-379.

DE WINTER, Lieven; TÜrSAN, Huri (eds.) (1998). Regionalist Parties in Western Europe. Londres: Routledge.

Diamandouros, Nikifors; Gunther, Richard (eds.) (2001). Parties, Politics and Democracy in New Southern Europe. Baltimore: Johns Hopkins University Press.

Duverger, Maurice (1957). Los partidos politicos. Madrid: Fondo de Cultura Económica.

EliasSEN, Kjell; SVASSAND, Lars (1975). «The formation of Mass Political Organizations: An Analytical Framework». Scandinavian Political Studies, X: 95-120.

Gallego, Javier (2003). El Parlamento de Navarra. Pamplona: Servicio de Publicaciones del Parlamento de Navarra. 
HERAS, Raul (1997). Enciclopedia politica y atlas electoral de la democracia española. Madrid: Temas de Hoy.

HopkIN, Jonathan; PAOLUCCI, Caterina (1999). «The business firm model of party organisation: Cases from Spain and Italy». European Journal of Political Research, vol. 35, 3: 307-339.

KATZ, Richard S.; MAIR, Peter (1995). "Changing Models of Party Organization and Party Democracy: The Emergence of the Cartel Party». Party Politics, 1: 5-28. KirCHHEIMER, Otto (1966). «The transformation of the western European party systems». En: LaPalombara, Joseph; Weiner, Myron (eds.). Political Parties and Political Development. Princeton: Princeton University Press, p. 177-200.

Koole, R. A. (1994). "The vulnerability of the modern cadre party in Netherlands». En: Katz, R.; MaIR, P. (eds.) (1994). How parties organize. Londres: Sage Publications.

KoPECKY, Peter (1995). «Developing party organizations in east-central Europe. What Type of Party is Likely to Emerge?». Party Politics, vol. 1, n. ${ }^{\circ} 4,515-534$.

Kostelecky, Tomas (2003). Political parties in post-communist eastern-Europe. Washington DC: Woodrow Wilson Center Press.

Krowel, André (2006). «Party Models». En: Katz, R.; CrotTy, W. (eds.). Handbook of Party Politics. Londres: Sage, p. 249-270.

LEWIS, Paul (2000). Political parties in post-communist eastern Europe. Londres: Routledge.

LLERA, Francisco J. (1997). "Continuidad y cambios en el sistema de partidos navarro: 1977-1987». Revista Internacional de Sociología, 47: 504-560.

LOPERENA, Demetrio (2002). «El acceso de Navarra a la autonomía vía amejoramiento». En: LANA, Miguel A. (coord.). En torno a la Navarra del siglo XX. Veintiún reflexiones acerca de sociedad, economía e historia. Pamplona: Universidad Pública de Navarra, p. 379-393.

Panebianco, Ángelo (1990). Modelos de partido. Madrid: Alianza Editorial.

Parlamento de Navarra (1994). Diez años del amejoramiento del fuero (1982-1992).

Pamplona: Servicio de Publicaciones del Parlamento de Navarra.

Pérez Calvo, Alberto (1999). «La posibilidad de incorporación de Navarra al País Vasco: disposición transitoria cuarta». En: AlZAGA, Oscar (ed.). Comentarios a la Constitución española de 1978. Madrid: Cortes Generales, p. 669-680.

RAMOS, Maria L.; INNERARITY, Carmen (1998). «Las elecciones autonómicas en la Comunidad Foral de Navarra». En: ALCÁNTARA, M.; MARTínEZ, A. (eds.). Las elecciones autonómicas en España. Madrid: Centro de Investigaciones Sociológicas, p. 383-411. RAZQUIN, Jose Antonio (1989). Derechos históricos y régimen foral de Navarra. Pamplona: Departamento de Presidencia e Interior.

SANTAMARía PASTOR, Alfonso (dir.) (1992). Comentarios a la Ley orgánica de reintegración del régimen foral de Navarra. Madrid: Ministerio para las Administraciones Públicas.

SeILER, Daniel L. (1982). Les parties autonomistes. París: PUF.

Ugalde, Ana; Arana, Ignacio (1989). «Navarra». En: Fusi, J. P. (dir.). EspañaAutonomías. Madrid: Espasa Calpe, p. 651-684.

Unión del Pueblo Navarro (1989). III Congreso. 1989. Documentación. Pamplona: UPN.

Unión del Pueblo Navarro (2005). Ponencia estatutaria [en línea]. [http://upn.org/component/option,com_docman/task,cat_view/gid,44/Itemid,55/]

VALENTÍn, Andrés (1991). «Materiales para un mapa electoral de Navarra». Revista Española de Investigaciones Sociológicas, 51: 121-170. 